\title{
Hypermethylation Profile
}

National Cancer Institute

\section{Source}

National Cancer Institute. Hypermethylation Profile. NCI Thesaurus. Code C129892.

The identification and quantitation of sites for DNA hypermethylation in the genome of a biological sample. 